\title{
Radiographic Evaluation of Developmental Stages of Third Molar in Relation to Chronological Age as Applicability in Forensic Age Estimation
}

\section{Arati S. Panchbhai}

Senior Lecture, Oral medicine and Radiology, Wardha, India

\begin{abstract}
Objectives: The need for age estimation is increasing day by day; difficulty in human age estimation after 14 years of age has greatly shifted the focus on third molar. Radiographic evaluation of presence, position and degree of third molar formation can be utilized in forensic age estimation. The present study aimed to evaluate the development of third molar in relation to chronological age.
\end{abstract}

Methods: The present study included sample of 479 subjects in the age range 5-30 years, for each subject, orthopantomograph was taken. To assess the developmental stages of third molars; the staging system described by Nolla [1] CM was used.

Results: Overall, no significant differences were observed in mean ages at which the developmental stages were reached in all four third molars. The absence of crypt was observed more for maxillary third molars, contrarily, stages 1 , 2, 3 were reached earlier in mandibular third molars. In case of presence of four completely developed third molars in a subject, the probability of an individual to be older than 18 years of age was $94.35 \%$ for females and $95.23 \%$ for males.

Conclusion: Third molar teeth are well known for their variability in development, eruption pattern, size, contour and relative positions as compare to other teeth. In spite of variations, third molars are still at the centre of medicolegal interest; and its significance in age determination is justified as no other reliable age indicator is available to determine the age in adults. Besides, it will help to separate adolescents from adults as jurisprudence differs for juvenile detainees.

Keywords: Third molar tooth; Age Estimation; Developmental Stages; Forensic Science; Forensic Odontology

\section{Introduction}

Age estimation is one of the vital criteria in establishing the identity of person. In forensic odontology, there is a need to estimate the chronological age in living individuals and in cadavers for various reasons. It is observed that the number of cases lacking age documentation and the number of unidentified cadavers and the human remains are increasing. In view of this, the need for age estimation is increasing day by day [2-6]

Difficulty in human age estimation after 14 years of age has greatly shifted the focus on development of third molar, also commonly referred to as wisdom teeth. Durability of dental structure makes it one of the materials of choice in age estimation as compare to skeletal method, which is influenced by exogenous factors [2,5,7-10]. Tooth or dentition being the hardest structure in the body survives every disaster such as fire accidents, bomb blast, plane crashes, mass disasters etc $[7,8,10]$. The multiple teeth in varied stage of dental development provide the sufficient data source for accurate age estimation, but only till the age of 14 years $[2,11,12]$. After the eruption of second permanent molar that is i. e. after $12-13$ years of age the only teeth remain to develop is the third molar $[13,14]$. The normal age of eruption of $3^{\text {rd }}$ molar in the oral cavity is 17-21 years followed by its root development in subsequent years [14]. The assessment of third molar development from initiation to its complete development in terms of various developmental stages can be implemented in age estimation of human being, especially after 14 years of age.

The third molar evaluation would be beneficial in various ways as in orthodontics, pedodontics, oral surgery and in assessing the possibility of autogenous tooth transplantation $[2,13]$. Importantly, it is increasingly being utilized in forensic sciences and in medicolegal implications to determine the age of undocumented youths $[3,4,6,12]$ plus in differentiating the juvenile from the adult status in criminal law cases. Additionally, it is of use in chronological age estimation in relation to college attendance, social benefits, employment and marriage $[2,4,5,13]$.

Radiographic evaluation of the presence, position and degree of third molar formation can be made use in human age estimation. The present study aimed to evaluate the development of third molar in relation to chronological age. Secondly, to assess the influence of age, gender, and location on the development of third molar.

\section{Material and Methods}

This institutional study included the sample size of 479 subjects in the age range 5-30 years comprised of various age groups. The gender wise and the age wise distribution of study subjects are shown in Table 1.

For each subject, the orthopantomograph of adequate quality was taken on PM 2002 proline CC (Planmeca) OPG machine. The selection criteria for inclusion in the sample were subjects with no history of medical disease or surgery that could affect the presence and development of third molars in addition to permanent dentition and no obvious dental pathology on the panoramic radiograph related to the third molars $[13,15,16]$. The radiographs were studied under improved visualization for the developmental stages of third molar.

To assess the developmental stages of third molars of maxilla and

*Corresponding author: Arati S. Panchbhai, Senior Lecture, Oral medicine and Radiology, Wardha, India, Tel: 6136226 2064; E-mail: artipanch@gmail.com

Received January 24, 2012; Accepted March 20, 2012; Published March 25 2012

Citation: Panchbhai AS (2012) Radiographic Evaluation of Developmental Stages of Third Molar in Relation to Chronological Age as Applicability in Forensic Age Estimation. Dentistry S1:002. doi:10.4172/2161-1122.S1-002

Copyright: @ 2012 Panchbhai AS . This is an open-access article distributed unde the terms of the Creative Commons Attribution License, which permits unrestricted use, distribution, and reproduction in any medium, provided the original author and source are credited. 
mandible, the staging system described by Nolla CM [1] was adopted. (Figure 1 and Table 3 ). Ten developmental stages were considered for each third molar tooth; from the appearance of the uncalcified tooth germ to the complete apical closure, and the stage 0 , which designates the total absence of tooth formation (absence or no evidence of bone crypt). Each particular stage corresponds to a particular developmental score, ranging from 1 to 10 . For each case, the developmental stage was determined for all third molars present on the orthopantomogram. The intraobserver and interobserver variability at intervals using random selection of radiographs for determination of developmental stages was found to be nonsignificant.

The data was subjected to statistical analysis.

\section{Statistical analysis}

For each study group, the number of third molars and mean ages at which each Nolla stage was reached was derived using Z-test. Variations in mean ages of each developmental stage among four third molars were calculated using ANOVA test. Comparison of Developmental stages of third molars according to gender were done using Z-test, and Pearson correlation coefficient test was used to correlate developmental stages reached in all four molars. In order to compare the developmental stages of third molars in between right and left quadrants and in between upper and lower quadrants, Wilcoxon test was used.

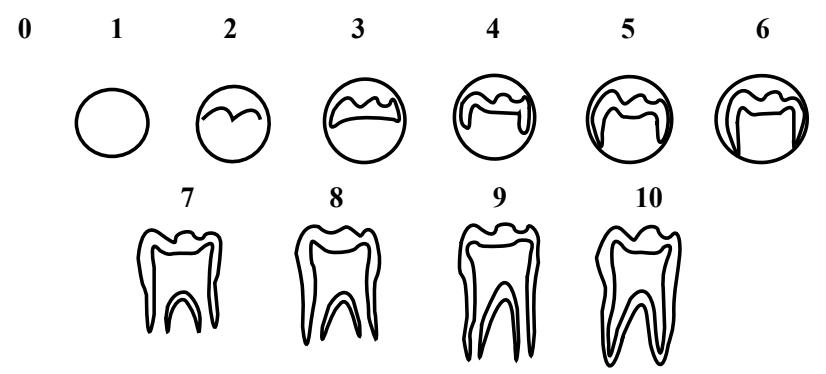

Figure 1: showing Nolla stages of development of third molar. Stage 0 - absence of crypt, Stage 1 - presence of crypt, Stage 2 - Initial calcification, Stage $3-1 / 3^{\text {rd }}$ crown completed, Stage $4-2 / 3^{\text {rd }}$ crown completed, Stage 5 - crown almost completed, Stage 6 - crown completed, Stage $7-1 / 3^{\text {rd }}$ crown completed, Stage $8-2 / 3^{\text {rd }}$ crown completed, Stage 9 - root completed, apex open, Stage 10 - apical foramen closed.

\begin{tabular}{|l|l|l|l|}
\hline Age groups (in years) & Male & Female & Total \\
\hline $5-10$ & 39 & 24 & 63 \\
\hline $11-15$ & 77 & 116 & 193 \\
\hline $16-22$ & 64 & 116 & 180 \\
\hline $23-30$ & 28 & 15 & 43 \\
\hline Total (5-30) & 208 & $\mathbf{2 7 1}$ & $\mathbf{4 7 9}$ \\
\hline
\end{tabular}

Table 1: Age groups and gender wise distribution of study subjects.

\begin{tabular}{|l|l|l|l|l|l|l|}
\hline $\begin{array}{l}\text { Tooth } \\
\text { (years) }\end{array}$ & $\begin{array}{l}\text { Average } \\
\text { Lenth of } \\
\text { crown } \\
\text { (mm) }\end{array}$ & $\begin{array}{l}\text { Average } \\
\text { Length of } \\
\text { Root } \mathbf{( m m})\end{array}$ & $\begin{array}{l}\mathbf{1}^{\text {st }} \\
\text { evidence } \\
\text { of calcifi- } \\
\text { cation }\end{array}$ & $\begin{array}{l}\text { Crown } \\
\text { done } \\
\text { (yrs) }\end{array}$ & $\begin{array}{l}\text { Age of emer- } \\
\text { gence in oral } \\
\text { cavity(yrs) }\end{array}$ & $\begin{array}{l}\text { Rone } \\
\text { (yrs) }\end{array}$ \\
\hline $\begin{array}{l}\text { Mandibular } \\
\mathbf{3}^{\text {rd }} \text { molar }\end{array}$ & 7.0 & 6.5 & $7-9$ & $12-16$ & $17-21$ & $18-25$ \\
\hline $\begin{array}{l}\text { Maxillary } \\
\mathbf{3}^{\text {rd }} \text { molar }\end{array}$ & 11.0 & 11.0 & $8-10$ & $12-16$ & $17-21$ & $18-25$ \\
\hline
\end{tabular}

$\mathrm{mm}=$ millimeters, $\mathrm{yrs}=$ years

Table 2: Average Length of Crown and root (millimetres) and Chronology of development of maxillary and mandibular third molars (years) by Wheeler RC et al.
To derive and compare the number of unformed (stage 0 ) or formed (any other stage than 0 ) third molars in each study group Chi-square test was used. Probabilities for an individual to be older than 18 years were calculated in case of third molars showing complete development.

The statistical analysis was performed using SPSS 10.0 software package.

\section{Results}

Table $3 \mathrm{~A}$ and $3 \mathrm{~B}$ shows the numbers of third molars and the mean ages at which each Nolla developmental stage (stages $0-10$ ) is reached in four third molars in study subjects. Overall, no significant differences were observed in mean ages at which the developmental stages were reached in all four third molars; the standard deviation for all age groups was in the range 0.14-1.96. In age group of 5-10 years, the stage 0 , that is the absence of crypt or no evidence of third molar formation was observed more in case of maxillary third molars as compare to mandibular third molars, contrarily, the stages $1,2,3$ were reached earlier in mandibular third molars. Variations in the mean ages at which each developmental stage was reached found to be insignificant among all four third molars. (Table 4)

Comparison of developmental stages of third molars according to gender found to be insignificant (Table 5). The significant positive correlation was observed between developmental stages of lower right and lower left third molars with high Pearson correlation coefficient of 0.91 in both males and females. The correlation was also positive for the upper arch in both males and females, with coefficient of 0.86 and 0.84 respectively (Table 6). The comparison of level of development of third molar in upper and lower quadrant and in between right and left quadrants found to be nonsignificant except for the upper arch in females (Table 7).

Considering the number of completely developed third molar teeth, the probability for an individual to be older than 18 years is expressed in Table 9. In case of the presence of four completely developed third molars in a subject, this probability was $94.35 \%$ for females and $95.23 \%$ for males. Table 10 shows the number and the comparison of maxillary and mandibular unformed (stage 0 ) or formed (any other stage) third molars for each quadrant in all age groups. Notably, the number of maxillary third molars in both quadrants at stage 0 was considerably higher than mandibular molars at this stage in all age groups.

\section{Discussion}

The present study included the subjects in age range from 5-30 years so that the development of third molars can be studied right from its initiation to root completion and thereafter, likewise the age groups are formulated (Table 1). Although, the sample range is wide in present study, the age range is narrowed down to four age groups to have the specificity of the study outcomes. Most of the previous studies have clubbed the study sample; on the contrary, the development of third molar should be studied separately in age groups as different developmental stages of third molar are reached in different age groups.

Wheeler RC and associates [14] have done extensive work on the dimensions, development and eruption of deciduous and permanent dentitions. Knowing the average size of crown and root [14] (Table 2 ), it was quite easier to assess the stages of development of crown and root of third molars as given by Nolla (Figure 1) [1]. Kullman et al. [17] studied the third molar development using two approaches; one is described as subjective, using the typical determination of developmental stages, and the objective, based on different digital 


\begin{tabular}{|c|c|c|c|c|c|c|c|c|c|c|c|c|}
\hline \multirow[t]{3}{*}{ Nolla Stages } & \multicolumn{3}{|c|}{ UR } & \multicolumn{3}{|c|}{ UL } & \multirow{2}{*}{\multicolumn{3}{|c|}{ 5-10 yearc }} & \multicolumn{3}{|c|}{ LL } \\
\hline & \multicolumn{9}{|c|}{ For age group $5-10$ years } & & & \\
\hline & $\mathrm{N}$ & $\begin{array}{l}\text { Mean age } \\
(95 \% \mathrm{Cl})\end{array}$ & SD & $\mathrm{N}$ & $\begin{array}{l}\text { Mean age } \\
(95 \% \mathrm{Cl})\end{array}$ & SD & $N$ & $\begin{array}{c}\text { Mean age } \\
(95 \% \mathrm{Cl})\end{array}$ & SD & $N$ & $\begin{array}{c}\text { Mean age } \\
(95 \% \mathrm{Cl})\end{array}$ & SD \\
\hline 0 & 49 & $\begin{array}{c}8.75 \\
(8.32-9.19)\end{array}$ & 1.51 & 48 & $\begin{array}{c}8.75 \\
(8.30-9.19)\end{array}$ & 1.52 & 28 & $\begin{array}{c}8.03 \\
(7.44-8.62)\end{array}$ & 1.51 & 34 & $\begin{array}{c}8.35 \\
(7.78-8.92)\end{array}$ & 1.63 \\
\hline 1 & 3 & $\begin{array}{c}9.73 \\
(8.13-11.33)\end{array}$ & 0.64 & 2 & $\begin{array}{c}10.10 \\
(8.82-11.37)\end{array}$ & 0.14 & 9 & $\begin{array}{c}9.72 \\
(8.86-10.57)\end{array}$ & 1.11 & 3 & $\begin{array}{c}9.66 \\
(8.23-11.10)\end{array}$ & 0.57 \\
\hline 2 & 1 & 10.00 & 0 & 4 & $\begin{array}{c}9.52 \\
(8.64-10.40)\end{array}$ & 0.55 & 15 & $\begin{array}{c}9.68 \\
(9.38-9.98)\end{array}$ & 0.54 & 16 & $\begin{array}{c}9.70 \\
(9.41-9.98)\end{array}$ & 0.53 \\
\hline 3 & 10 & $\begin{array}{c}9.85 \\
(9.39-10.30)\end{array}$ & 0.19 & 9 & $\begin{array}{c}9.83 \\
(9.32-10.34)\end{array}$ & 0.66 & 11 & $\begin{array}{c}9.91 \\
(9.48-10.34)\end{array}$ & 0.64 & 10 & $\begin{array}{c}9.85 \\
(9.39-10.30)\end{array}$ & 0.63 \\
\hline \multicolumn{13}{|c|}{ For age group $11-15$ years } \\
\hline & $\mathbf{N}$ & $\begin{array}{l}\text { Mean age } \\
(95 \% \mathrm{Cl})\end{array}$ & SD & $\mathbf{N}$ & $\begin{array}{l}\text { Mean age } \\
(95 \% \mathrm{Cl})\end{array}$ & SD & $\mathbf{N}$ & $\begin{array}{l}\text { Mean age } \\
(95 \% \mathrm{Cl})\end{array}$ & SD & $\mathbf{N}$ & $\begin{array}{l}\text { Mean age } \\
(95 \% \mathrm{Cl})\end{array}$ & SD \\
\hline 0 & 37 & $\begin{array}{c}12.69 \\
(12.26-13.12)\end{array}$ & 1.28 & 35 & $\begin{array}{c}12.65(12.16- \\
13.13)\end{array}$ & 1.41 & 11 & $\begin{array}{c}12.67(11.87- \\
13.47)\end{array}$ & 1.19 & 17 & $\begin{array}{c}12.99 \\
(12.37-13.60)\end{array}$ & 1.19 \\
\hline 1 & 4 & $\begin{array}{c}12.25 \\
(11,45-13.04)\end{array}$ & 0.50 & 2 & $\begin{array}{c}12.50 \\
(6.14-18.85)\end{array}$ & 0.70 & 6 & $\begin{array}{c}12.18(10.96- \\
13.40)\end{array}$ & 1.16 & 8 & $\begin{array}{c}11.77 \\
(11.02-12.52)\end{array}$ & 0.89 \\
\hline 2 & 15 & $\begin{array}{c}11.98 \\
(11.41-12.56)\end{array}$ & 1.03 & 15 & $\begin{array}{c}12.13 \\
(11.48-12.78)\end{array}$ & 1.17 & 25 & $\begin{array}{c}12.39(11.88- \\
12.90)\end{array}$ & 1.23 & 19 & $\begin{array}{c}12.35 \\
(11.78-12.92)\end{array}$ & 1.18 \\
\hline 3 & 51 & $\begin{array}{c}12.63 \\
(12.29-12.97)\end{array}$ & 1.21 & 61 & $\begin{array}{c}12.68(12.40- \\
12.96)\end{array}$ & 1.09 & 54 & $\begin{array}{c}12.36(12.07- \\
12.65)\end{array}$ & 1.05 & 53 & $\begin{array}{c}12.41 \\
(12.12-12.70)\end{array}$ & 1.04 \\
\hline 4 & 28 & $\begin{array}{c}13.50 \\
(13.05-13.95)\end{array}$ & 1.16 & 21 & $\begin{array}{c}13.51 \\
(13.02-14.01)\end{array}$ & 1.08 & 43 & $\begin{array}{c}13.54(13.18- \\
13.90)\end{array}$ & 1.15 & 40 & $\begin{array}{c}13.47 \\
(13.08-3.86)\end{array}$ & 1.21 \\
\hline 5 & 14 & $\begin{array}{c}13.85 \\
(13.19-14.51)\end{array}$ & 1.14 & 15 & $\begin{array}{c}13.93 \\
(13.30-14.56)\end{array}$ & 1.14 & 11 & $\begin{array}{c}13.91(13.11- \\
14.72)\end{array}$ & 1.19 & 12 & $\begin{array}{c}13.84 \\
(13.09-14.58)\end{array}$ & 1.17 \\
\hline 6 & 24 & $\begin{array}{c}13.22 \\
(12.75-13.69)\end{array}$ & 1.11 & 25 & $\begin{array}{c}13.29 \\
(12.82-13.77)\end{array}$ & 1.14 & 21 & $\begin{array}{c}13.22(12.69- \\
13.75)\end{array}$ & 1.15 & 22 & $\begin{array}{c}13.35 \\
(12.81-13.88)\end{array}$ & 1.19 \\
\hline 7 & 12 & $13.98(13.21-14.75)$ & 1.21 & 12 & $\begin{array}{c}13.77 \\
(12.83-14.71) \\
\end{array}$ & 1.47 & 16 & $\begin{array}{c}14.05(13.48- \\
14.61)\end{array}$ & 1.06 & 15 & $\begin{array}{c}13.88 \\
(13.14-14.63)\end{array}$ & 1.34 \\
\hline 8 & 4 & $\begin{array}{c}14.75 \\
(13.95-15.54)\end{array}$ & 0.50 & 4 & $\begin{array}{c}14.75 \\
(13.95-15.54)\end{array}$ & 0.50 & 3 & $15.00(15-15)$ & 0.00 & 3 & $\begin{array}{c}15.00 \\
(15-15)\end{array}$ & 0.00 \\
\hline 9 & 2 & $15.00(15-15)$ & 0.00 & 2 & $15.00(15-15)$ & 0.00 & 2 & $15.00(15-15)$ & 0.00 & 2 & $15.00(15-15)$ & 0.00 \\
\hline 10 & 1 & $15.00(-)$ & -- & 1 & $15.00(-)$ & -- & 1 & $15.00(-)$ & -- & 1 & $15.00(-)$ & -- \\
\hline
\end{tabular}

$\mathrm{N}=$ Number of third molars, UR-upper right third molar, UL- upper left third molar , LR- lower right third molar, LL- lower left third molar, SD - standard deviation Table 3A: Number of third molars and mean ages at which each Nolla stage is reached in study groups of 5-10 years and 11-15 years.

\begin{tabular}{|c|c|c|c|c|c|c|c|c|c|c|c|c|}
\hline \multirow{3}{*}{$\begin{array}{l}\text { Nolla } \\
\text { Stages }\end{array}$} & \multicolumn{3}{|c|}{ UR } & \multicolumn{3}{|c|}{ UL } & \multicolumn{3}{|c|}{ LR } & \multicolumn{3}{|c|}{ LL } \\
\hline & \multicolumn{12}{|c|}{ For age group $16-22$ years } \\
\hline & $\mathrm{N}$ & Mean $(95 \% \mathrm{Cl})$ & SD & $\mathrm{N}$ & Mean $(95 \% \mathrm{Cl})$ & SD & $\mathrm{N}$ & Mean $(95 \% \mathrm{Cl})$ & SD & $\mathrm{N}$ & Mean $(95 \% \mathrm{Cl})$ & SD \\
\hline 0 & 31 & $\begin{array}{c}19.12 \\
(18.53-19.71)\end{array}$ & 1.60 & 22 & $\begin{array}{c}19.04(18.35- \\
19.72)\end{array}$ & 1.55 & 13 & $\begin{array}{c}18.69(17.72- \\
19.66)\end{array}$ & 1.60 & 13 & $\begin{array}{c}18.76(17.77- \\
19.76)\end{array}$ & 1.64 \\
\hline 1 & -- & -- & -- & -- & -- & -- & -- & -- & -- & -- & -- & -- \\
\hline 2 & -- & -- & -- & -- & -- & -- & -- & -- & -- & -- & -- & -- \\
\hline 3 & 1 & $17.00(-)$ & -- & 2 & $\begin{array}{c}18.00(15.29- \\
21.70)\end{array}$ & 1.41 & 1 & $16.00(-)$ & -- & 1 & $16.00(-)$ & -- \\
\hline 4 & 6 & $\begin{array}{c}18.83 \\
(16.79-20.87)\end{array}$ & 1.94 & 4 & $\begin{array}{c}18.50(14.71- \\
22.28)\end{array}$ & 2.38 & 4 & $\begin{array}{c}17.75 \\
(14.22-21.27)\end{array}$ & 2.21 & 4 & $\begin{array}{c}17.75 \\
(14.22-21.27)\end{array}$ & 2.21 \\
\hline 5 & 3 & $\begin{array}{c}17.00 \\
(17-17)\end{array}$ & 0.00 & 4 & $\begin{array}{c}18.80(15.45- \\
22.14)\end{array}$ & 2.10 & 1 & $\begin{array}{c}17.00 \\
(16.26-20.39)\end{array}$ & -- & 1 & $17.00(-)$ & -- \\
\hline 6 & 12 & $\begin{array}{c}17.80 \\
(16.16-19.43)\end{array}$ & 2.43 & 11 & $\begin{array}{c}17.78(16.15- \\
19.40)\end{array}$ & 2.41 & 6 & $\begin{array}{c}18.33 \\
(17.59-18.79)\end{array}$ & 1.96 & 7 & $\begin{array}{c}18.57 \\
(16.81-20.33)\end{array}$ & 1.90 \\
\hline 7 & 27 & $\begin{array}{c}18.29 \\
(17.64-18.94)\end{array}$ & 1.57 & 33 & $\begin{array}{c}18.58(18.02- \\
19.14)\end{array}$ & 1.58 & 38 & $\begin{array}{c}18.19 \\
(17.56-18.94)\end{array}$ & 1.83 & 38 & $\begin{array}{c}18.24 \\
(17.64-18.85)\end{array}$ & 1.84 \\
\hline 8 & 13 & $\begin{array}{c}17.52 \\
(16.69-18.34) \\
\end{array}$ & 1.36 & 14 & $\begin{array}{c}17.27(16.63- \\
17.91)\end{array}$ & 1.10 & 20 & $\begin{array}{c}18.25 \\
(19.54-20.60)\end{array}$ & 1.47 & 19 & $\begin{array}{c}17.94 \\
(17.30-18.58)\end{array}$ & 1.32 \\
\hline 9 & 15 & $\begin{array}{c}20.10 \\
(19.45-20.74)\end{array}$ & 1.21 & 16 & $\begin{array}{c}19.97(19.32- \\
20.62)\end{array}$ & 1.21 & 22 & $\begin{array}{c}20.07 \\
(19.79-20.35)\end{array}$ & 1.19 & 24 & $\begin{array}{c}19.93 \\
(19.41-20.45)\end{array}$ & 1.23 \\
\hline 10 & 74 & $\begin{array}{c}20.01 \\
(19.72-20.30) \\
\end{array}$ & 1.25 & 74 & $\begin{array}{c}20.08(19.79- \\
20.37)\end{array}$ & 1.24 & 75 & $\begin{array}{c}20.07 \\
(19.48-20.66)\end{array}$ & 1.22 & 72 & $\begin{array}{c}20.16 \\
(19.89-20.44)\end{array}$ & 1.17 \\
\hline
\end{tabular}

$\mathrm{N}=$ Number of third molars, UR-upper right third molar, UL- upper left third molar , LR- lower right third molar, LL- lower left third molar, SD - standard deviation Table 3B: Number of third molars and mean ages at which each Nolla stage is reached in study groups of 16-22 years. 


\begin{tabular}{|l|l|l|l|l|l|}
\hline $\begin{array}{l}\text { Stag- } \\
\text { es }\end{array}$ & UR & UL & LR & LL & \\
\hline & Mean & Mean & Mean & Mean & p-value \\
\hline $\mathbf{0}$ & $13.57(5-30)$ & $13.04(5-30)$ & $12.57(5-30)$ & $12.58(5-30)$ & 0.05, NS \\
\hline $\mathbf{1}$ & $11.17(9-13)$ & $11.30(10-13)$ & $\begin{array}{l}10.70(6.80- \\
13.80)\end{array}$ & $11.20(9-13.10)$ & 0.06, NS \\
\hline $\mathbf{2}$ & $11.86(10-14)$ & $11.58(9-15)$ & $11.37(9-15)$ & $11.14(9-15)$ & $0.52, N S$ \\
\hline $\mathbf{3}$ & $12.25(9-17)$ & $12.47(9-19)$ & $12.01(9-16)$ & $12.07(9-16)$ & $0.43, N S$ \\
\hline $\mathbf{4}$ & $14.44(11.10-21)$ & $14.65(12-23)$ & $13.90(11-21)$ & $13.86(11-21)$ & $0.07, N S$ \\
\hline $\mathbf{5}$ & $14.25(12-17)$ & $14.95(12-21)$ & $14.17(12-17)$ & $14.08(12-17)$ & $0.08, N S$ \\
\hline $\mathbf{6}$ & $14.66(11-22)$ & $14.66(11-22)$ & $14.35(11-22)$ & $14.61(11-22)$ & 0.07, NS \\
\hline $\mathbf{7}$ & $17.20(12-23)$ & $17.65(11.10-23)$ & $17.18(12-23)$ & $17.23(11.10-23)$ & $0.09, N S$ \\
\hline $\mathbf{8}$ & $17.62(14-25)$ & $17.44(14-25)$ & $18.12(15-25)$ & $17.86(15-25)$ & $0.10, N S$ \\
\hline $\mathbf{9}$ & $19.87(15-26)$ & $20.13(15-27)$ & $19.90(15-26)$ & $20.05(15-27)$ & $0.08, N S$ \\
\hline $\mathbf{1 0}$ & $21.63(15-30)$ & $21.65(15-30)$ & $21.87(15-30)$ & $21.92(15-30)$ & $0.07, N S$ \\
\hline
\end{tabular}

NS = nonsignificant, $p$-value - probability value

Table 4: Variations in mean ages of each developmental stages among four third molars.

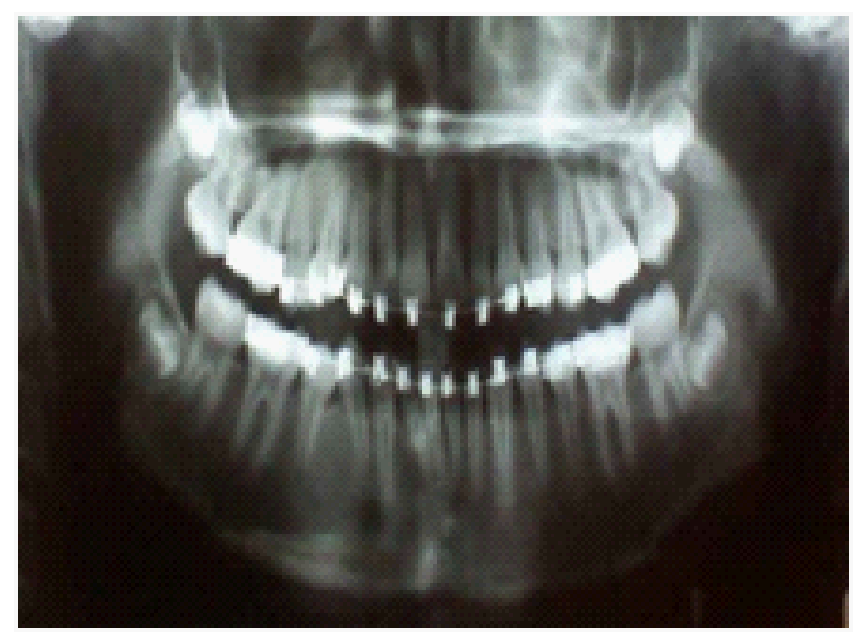

Figure 2: shows early crown formation in maxillary third molar as compare to mandibular third molars.

\begin{tabular}{|l|l|l|l|}
\hline Tooth & Gender & Mean \pm SD & p-value \\
\hline UR & Male & $5.25 \pm 4.01$ & $0.81, \mathrm{NS}$ \\
\hline & Female & $5.16 \pm 3.66$ & \\
\hline UL & Male & $5.30 \pm 3.93$ & $0.76, \mathrm{NS}$ \\
\hline & Female & $5.41 \pm 3.52$ & \\
\hline LR & Male & $5.81 \pm 3.65$ & $0.79, \mathrm{NS}$ \\
\hline & Female & $5.90 \pm 3.32$ & \\
\hline LL & Male & $5.63 \pm 3.73$ & $0.41, \mathrm{NS}$ \\
\hline & Female & $5.90 \pm 3.33$ & \\
\hline
\end{tabular}

Table 5: Comparison of Developmental stages of third molars according to gender.

measurements of root length and other third molar parameters. It was shown the objective methods do not improve the accuracy of age estimations over subjective methods.

Overall, no significant differences were observed in mean ages at which the developmental stages were reached in all four third molars. In general, the stage 0 that is the absence of crypt or no evidence of third molar formation was observed more in case of maxillary third molars, while the higher number of mandibular third molars showed stages 1 , 2, 3 and 4 as compared to maxillary molars (Table 3A, 3B). Although, the initiation of third molar (Stage 1) was earlier in mandibular molars, stages 5 and 6 were reached earlier in maxillary third molars indicating the early crown formation in maxillary third molar (Figure 2). This observation is in line with those of Gorgani et al. [18], Bolanos et al. [12] and Uzamis et al. [19] It is the only the initiation which is making difference in the maxillary and mandibular molars, rest of the stages occur at the same ages with insignificant differences.

Few subjects in the age of 5 to 6 years were included in the present study to observe the evidence of third molar in these age categories. The earliest age at which the evidence of crypt (Stage 1) observed was 6.8 years in one subject who showed the presence of crypt for third molar in lower right quadrant. The stage 0 was observed in around 8-9 years of age range with standard deviation of 1.63 years, after which the initiation of third molar can be expected. According to Wheelers chronology of development, the first evidence of calcification for the lower third molar is at 7-9 years of age while for upper third molar, it is $8-10$ years of age. In the present study, the stage 3 was reached by 10 years of age; none of the third molar in age group 5-10 years reached the stage 4 . The developmental stages observed in age group 11-15 years were mainly the stages 3 to 7 . Complete crown formation (Nolla stage 6) was reached at around the mean age of 13.25 years with age variability of maximum 1.19 years (Table $3 \mathrm{~A}$ ). The developmental stages predominantly reached in age group 16-22 years were stage 7 to 10. The developmental stage 9 (complete root formation, apex open) was reached at mean age of 20 years with maximum age variability of 1.23 years as indicated by standard deviation (Table 3B). Previously, studies showed the mean age for stage 6 as 14 years and for stage 9 as 18 years with 2 years of variability [6,13]. According to Wheelers [14], the age for crown completion is in the range of 12-16 years and for root completion is 17-21 years. The present study results lie in these age ranges.

The age group 25-30 years was included in the study to assess if third molars continue development after 23-25 years by which the root formation is supposed to have been completed. Only, 7 out of 43 subjects did not show the completed development while rest were at stage 10 . Out of these 7 , in 3 subjects third molars were in stage 9 and rest 4 subjects belonged to age category of 23 years showed third molars in varied stages of development as 4,7 and 8 .

Variations in the mean ages of each developmental stage among four third molars were found to be insignificant suggesting more or less similar degree of development in all four third molars.

Although, the developmental stages showed predilection for particular age groups, in few subjects third molars showed variability in these predilection, e. g. the initiation of third molar (stage 1) was observed in age group 11-15 years with considerable number of cases showing third molars in stage 2 (Table $3 \mathrm{~A}$ ). While in age group 1622 years, few subjects showed third molars in developmental stages 3 to 6 . Thus any developmental stage can be observed in any age group indicating the variability in the development of third molar, although in few proportions.

Gender wise comparison of study subjects for the developmental stages of third molar revealed no significant differences in the degree of formation of four third molars in males and females, although there was a trend for earlier development in males than females. This in agreement to some of the previous studies $[2,5,11,17,20,21]$ while in contradiction to study by Solari et al. [20] and Chandrmohan et al. [15] who find significant differences in development in males and females (Table 5).

Pearson correlation coefficient was used to assess the left-right 


\begin{tabular}{|l|c|c|c|c|c|}
\hline $\begin{array}{c}\text { Groups (Pearson Correla- } \\
\text { tion test) }\end{array}$ & $\begin{array}{c}\text { Third } \\
\text { Molars }\end{array}$ & UR & UL & LR & LL \\
\hline \multirow{4}{*}{ Male } & UR & 1 & 0.86 & 0.76 & 0.72 \\
\cline { 2 - 6 } & UL & 0.86 & 1 & 0.77 & 0.76 \\
\cline { 2 - 6 } & LR & 0.76 & 0.77 & 1 & 0.91 \\
\cline { 2 - 6 } & LL & 0.72 & 0.76 & 0.91 & 1 \\
\hline \multirow{3}{*}{ Female } & UR & 1 & 0.84 & 0.74 & 0.76 \\
\hline & UL & 0.84 & 1 & 0.78 & 0.79 \\
\hline & LR & 0.74 & 0.78 & 1 & 0.91 \\
\hline & LL & 0.76 & 0.79 & 0.91 & 1 \\
\hline
\end{tabular}

Table 6: Correlation of developmental stages between upper and lower third molars in males and females.

\begin{tabular}{|c|c|c|c|c|}
\hline \multicolumn{5}{|c|}{ Between upper and lower quadrants } \\
\hline Tooth & Male & $\begin{array}{c}\text { p-value } \\
\text { (Wilcoxon test) }\end{array}$ & Female & p-value \\
\hline & \multicolumn{4}{|c|}{} \\
\hline UR & $5.25 \pm 4.01$ & $0.000, \mathrm{~S}$ & $5.16 \pm 3.66$ & $0.000, \mathrm{~S}$ \\
\hline LR & $5.81 \pm 3.65$ & & $5.90 \pm 3.32$ & \\
\hline UL & $5.30 \pm 3.93$ & $0.010, \mathrm{~S}$ & $5.41 \pm 3.52$ & $0.002, \mathrm{~S}$ \\
\hline LL & $5.63 \pm 3.73$ & & $5.90 \pm 3.33$ & \\
\hline \multicolumn{5}{|c|}{ Between right and left quadrants } \\
\hline Tooth & Male & $\begin{array}{c}\text { p-value } \\
\text { (Wilcoxon test) }\end{array}$ & Female & p-value \\
\hline UR & $5.25 \pm 4.01$ & 0.66, NS & $5.16 \pm 3.66$ & $0.04, S$ \\
\hline UL & $5.30 \pm 3.93$ & & $5.41 \pm 3.52$ & \\
\hline LR & $5.81 \pm 3.65$ & 0.77, NS & $5.90 \pm 3.32$ & $0.16, N S$ \\
\hline LL & $5.63 \pm 3.73$ & & $5.90 \pm 3.33$ & \\
\hline
\end{tabular}

$\mathrm{S}=$ significant, $\mathrm{NS}=$ nonsignificant

Table 7: Comparison of third molar development in upper and lower quadrants and in right and left quadrants of the jaws.

\begin{tabular}{|c|c|c|c|c|c|c|c|c|c|}
\hline $\begin{array}{l}\text { Age category in } \\
\text { years Total }(n)\end{array}$ & \begin{tabular}{|l|}
15 \\
$(18)$
\end{tabular} & $\begin{array}{l}16 \\
(19)\end{array}$ & \begin{tabular}{|l|}
17 \\
$(16)$
\end{tabular} & $\begin{array}{l}18 \\
(21)\end{array}$ & $\begin{array}{l}19 \\
(37)\end{array}$ & $\begin{array}{l}20 \\
(47)\end{array}$ & $\begin{array}{l}21 \\
(24)\end{array}$ & \begin{tabular}{|l|}
22 \\
$(16)$
\end{tabular} & $\begin{array}{l}23 \\
(8)\end{array}$ \\
\hline $\begin{array}{l}\text { \% of subjects } \\
\text { showing complete } \\
\text { development of 3rd } \\
\text { molars }(n)\end{array}$ & $\begin{array}{l}5.55 \\
(1)\end{array}$ & $\begin{array}{l}5.26 \\
(1)\end{array}$ & $\begin{array}{l}6.25 \\
(2)\end{array}$ & $\begin{array}{l}23.81 \\
(5)\end{array}$ & $\begin{array}{l}54.05 \\
(20)\end{array}$ & $\begin{array}{l}72.34 \\
(34)\end{array}$ & $\begin{array}{l}54.17 \\
(13)\end{array}$ & $\begin{array}{l}75 \\
(12)\end{array}$ & $\begin{array}{l}75 \\
(6)\end{array}$ \\
\hline $\begin{array}{l}\text { \% of subjects } \\
\text { showing complete } \\
\text { development of all } 4 \\
\text { third molars }(n)\end{array}$ & $\begin{array}{l}5.55 \\
(1)\end{array}$ & $\begin{array}{l}0 \\
(-)\end{array}$ & $\begin{array}{l}3.13 \\
(1)\end{array}$ & $\begin{array}{l}14.29 \\
(3)\end{array}$ & $\begin{array}{l}27.02 \\
(10)\end{array}$ & $\begin{array}{l}40.43 \\
(19)\end{array}$ & $\begin{array}{l}45.83 \\
(11)\end{array}$ & $\begin{array}{l}62.5 \\
(10)\end{array}$ & $\begin{array}{l}37.5 \\
(3)\end{array}$ \\
\hline $\begin{array}{l}\% \text { of subjects } \\
\text { showing complete } \\
\text { development of }<4 \\
\text { third molars }(n)\end{array}$ & $\begin{array}{l}0 \\
(-)\end{array}$ & $\begin{array}{l}5.26 \\
(1)\end{array}$ & $\begin{array}{l}3.12 \\
(1)\end{array}$ & $\begin{array}{l}4.76 \\
(2)\end{array}$ & $\begin{array}{l}27.02 \\
(10)\end{array}$ & $\begin{array}{l}31.91 \\
(15)\end{array}$ & $\begin{array}{l}8.33 \\
(2)\end{array}$ & $\begin{array}{l}12.5 \\
(2)\end{array}$ & $\begin{array}{l}37.5 \\
(3)\end{array}$ \\
\hline
\end{tabular}
complete development of third molars in $<18$ yrs and $>18$ years of age categories.

symmetry in third molar development in both jaws. The significant positive correlation was observed between developmental stages of lower right and lower left third molars with high Pearson correlation coefficient of 0.91 in both males and females. In addition, the correlation was significantly positive for the upper arch in both males and females, though not as stronger as was observed in lower arch with coefficient of 0.86 and 0.84 respectively (Table 6). This were in contradiction to Mesoten et al. [15] and Gunst et al. [5] who revealed highest coefficient for developmental stages between upper right and upper left third molars than in lower quadrants.

The differences in the level of development of third molar in upper and lower quadrants and in between right and left quadrants found to be nonsignificant except for the upper arch in females (Table 7). In general, the similar degrees of development of stages were observed in maxilla and in mandible on both sides, although, mandibular third molars presented earlier trend in formation of stages with respect to maxillary third molars on both sides (Table 7). Contrarily, results by Bolanos et al. [13] and Solari et al. [20] demonstrated the maxillary molars to present stages at earlier age than mandibular ones.

The number and the percentage of third molars showing complete development (stage 10) in individuals less than 18 yrs of age and above 18 years of age categories are expressed in Table 8 . Very few, that is $7.54 \%$ subjects ( 4 out of 53 subjects) below 18 years showed complete development of third molar while $23.81 \%$ subject of 18 years of age and the significant number of subjects above 18 years of age showed complete development of third molars. Completion of third molar before the age of 18 years adds to variability in development of third molar, however, it is to be noted that very negligible proportion of third molars have reached the stage 10 before 18 years of age (Table 8 ). This suggests that linking the completion of third molar development with 18 years of age and above will not be irrational.

Considering the number and locations of completely developed third molars, the probability of an individual to be older than 18 years is

\begin{tabular}{|c|c|c|}
\hline Chance $>$ 18 yrs $\mathbf{( \% )}$ & Male & Female \\
\hline $\mathrm{UR}(=10)$ & 83.00 & 84.00 \\
\hline $\mathrm{UL}(=10)$ & 87.20 & 88.40 \\
\hline $\mathrm{LR}(=10)$ & 92.30 & 93.10 \\
\hline $\mathrm{LR}(=10)$ & 94.50 & 92.50 \\
\hline $\mathrm{UR+}+\mathrm{LL}=10$ & 95.32 & 91.21 \\
\hline $\mathrm{LR}+\mathrm{LL}=10$ & 94.23 & 92.23 \\
\hline UR+UL+LR+LL=10 & 95.23 & 94.35 \\
\hline
\end{tabular}

Table 9: Probability of an individual to be older than 18 years in case of complete third molar development (Developmental Stage 10).

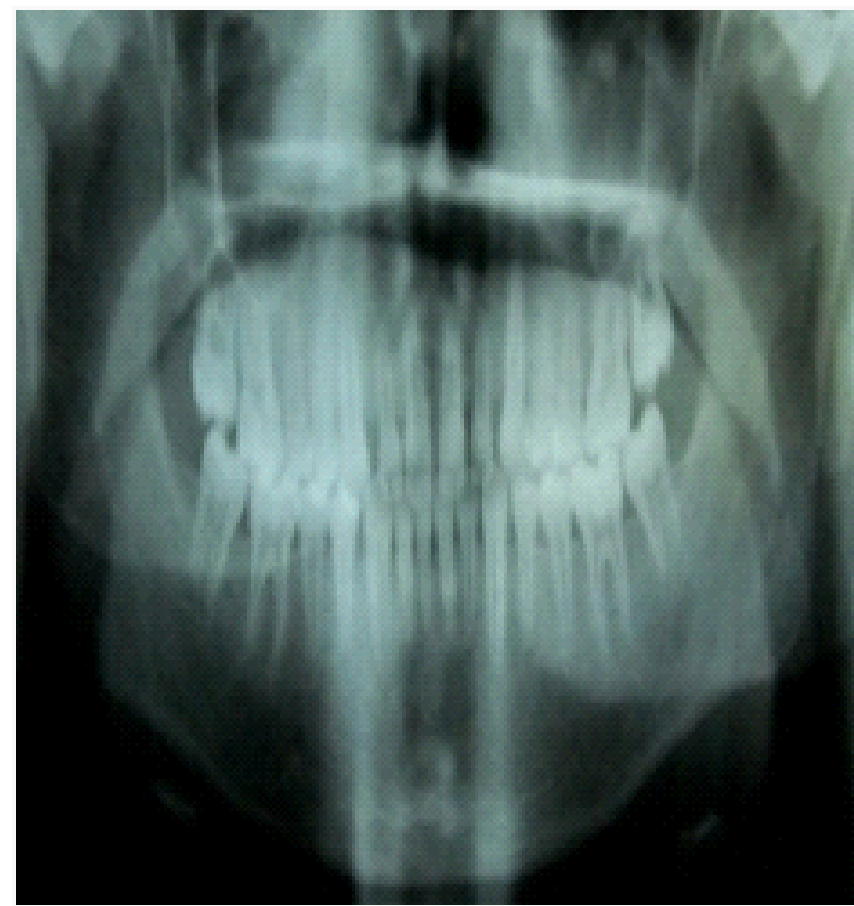

Figure 3: showing agenesis of each of the four third molars in 15 year old female. 
derived (Table 9). In case of the presence of four completely developed third molar teeth, the probability for an individual to be older than 18 years was $94.35 \%$ for females and $95.23 \%$ for males. These results were corresponding to findings by Gunst et al. [5] The present study is one of those very few studies which calculated such probabilities in case of completely developed third molar teeth.

The present study also assessed the prevalence of agenesis among third molars in study sample. In whole of the study sample, the prevalence of agenesis was found to be $30.69 \%$, it is recorded to be $20.33 \%$ excluding age group 5-10 years as the initiation may be late in

\begin{tabular}{|c|c|c|c|c|c|}
\hline Age groups & & UR & UL & LR & LL \\
\hline \multirow[t]{3}{*}{$5-10$ yrs } & Stage 0 & 49 & 48 & 28 & 34 \\
\hline & Stage $>0$ & 14 & 15 & 35 & 29 \\
\hline & א2-value & $\begin{array}{c}\text { 45.41, } \\
p<0.0001, s\end{array}$ & $\begin{array}{c}\text { 41.13, } \\
p<0.0001, S\end{array}$ & $\begin{array}{r}15.51 \\
P=0.002, S\end{array}$ & $\begin{array}{c}\text { 23.11, } \\
P=0.003, S\end{array}$ \\
\hline \multirow[t]{3}{*}{$11-15$ yrs } & Stage 0 & 33 & 30 & 11 & 16 \\
\hline & Stage $>0$ & 128 & 131 & 150 & 145 \\
\hline & א2-value & $\begin{array}{c}\text { 43.21, } \\
p<0.0001, S\end{array}$ & $\begin{array}{c}32.13 \\
p<0.0001, S\end{array}$ & $\begin{array}{c}33.21, \\
p<0.0001, s\end{array}$ & $\begin{array}{c}43.12, \\
p<0.0001, s\end{array}$ \\
\hline \multirow[t]{3}{*}{$16-22$ yrs } & Stage 0 & 38 & 28 & 16 & 17 \\
\hline & Stage $>0$ & 185 & 195 & 207 & 206 \\
\hline & א2-value & $\begin{array}{c}33.21, \\
p<0.0001, s\end{array}$ & $\begin{array}{c}31.13 \\
p<0.0001, s\end{array}$ & $\begin{array}{c}34.21, \\
p<0.0001, s\end{array}$ & $\begin{array}{c}33.12, \\
p<0.0001, s\end{array}$ \\
\hline
\end{tabular}

$p=$ probability value, $S=$ significant

Table 10: Number of maxillary and mandibular unformed (stage 0 ) or formed (any other stage) third molars in all age groups.

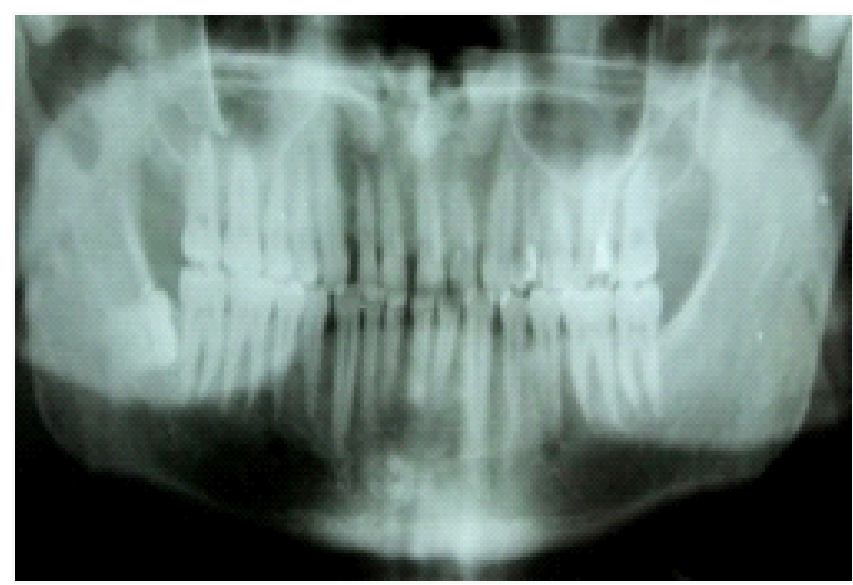

Figure 4: shows bilateral agenesis in maxillary third molars in 29 year old male. third molars. The agenesis of each of the four third molars was (Figure 3) seen in $7.52 \%$ subjects in whole of the study sample and the agenesis of less than 4 third molars was seen in $23.17 \%$ (Table 11). Arany et al. [2] also reported agenesis of each of the four third molars in $7 \%$ of all the patients.

Some of the studies have expressed prevalence of agenesis to be ranging from $7-10 \%$ to $32.4 \%[18,22,23]$ The agenesis was more commonly observed in case of maxillary third molars than the mandibular third molar (Table 10) which is similar to that observed in study by Bolanos et al. [13] and Arany et al. [2] who reported maxillary agenesis with double frequency as compared to mandibular agenesis. This is contradictory to Llarena del Rosario et al. [23] who found third molar agenesis in higher cases in the mandible.

In the present study, the most frequent situation was the agenesis (no radiological visualization) of 2 third molars followed by 1 third molar and then 3 third molars missing in the study sample (Table 11). Prevalence of bilateral agenesis of third molars was found to be 9.13\% in maxillary third molars as compared to $0.72 \%$ in mandibular third molars in subjects in the age range 11-30 years. This higher prevalence of bilateral agenesis in maxillary third molars (Figure 4) is in contradiction to results by previous studies who showed greater prevalence in mandibular third molars $[6,13,18]$ While gender wise no differences were observed in predilection for third molar agenesis.

The diagnosis of agenesis of maxillary third molar must be made with great care as maxillary third molars are difficult to identify at initial stages of their development owing to distortions and superposition of anatomical structures in the region of development of maxillary third molar in orthopantomograph. Hence, maxillary third molars may not be visible or may go undetected in the maxilla [13].

From the aspect of the forensic odontologist, reliability and adequate precision of age determination using third molars is crucially important. The accuracy of dental age estimation in adults using third molar has always been a questionable issue owing to great variability in its development. Uncertainties emerge mainly from significant individual differences in the developmental pattern of third molar due to its variations in eruption pattern, size, contour and relative positions as compare to other teeth and frequent absence due to extraction or congenitally lack or the impactions due to lack of space $[2,13,14]$. In addition, the population differences, varied sample size and age range, and the subjectivity in application of method in the studies conducted so far may contribute to differences in study outcomes.

Mincer et al. [21], Bassed et al. [22] and Prabhakaran et al. [23]

\begin{tabular}{|c|c|c|c|c|c|c|c|}
\hline \multirow[b]{2}{*}{ Age groups (n) } & \multirow{2}{*}{$\begin{array}{l}\text { Total of missing } \\
\text { molars \% (n) }\end{array}$} & \multirow[b]{2}{*}{$\begin{array}{l}\text { Gender wise } \\
\text { groups }\end{array}$} & \multirow[b]{2}{*}{$\begin{array}{c}\text { All } 4 \text { third molars } \\
\text { missing }\end{array}$} & \multicolumn{4}{|c|}{$<4$ third molars missing } \\
\hline & & & & Total \% (n) & $\begin{array}{l}3 \text { molars } \\
\text { missing(n) }\end{array}$ & $\begin{array}{l}2 \text { molars } \\
\text { Missing(n) }\end{array}$ & $\begin{array}{c}1 \text { molar } \\
\text { Missing(n) }\end{array}$ \\
\hline \multirow[t]{3}{*}{$5-10$ yrs $(n=63)$} & $79.37 \%(50)$ & Male & 13 & 17 & 5 & 8 & 4 \\
\hline & & Female & 9 & 11 & 6 & 4 & 1 \\
\hline & & Total \% & $14.29 \%(22)$ & $44.44 \%(28)$ & 11 & 12 & 5 \\
\hline \multirow[t]{3}{*}{$11-15$ yrs $(n=193)$} & $24.87 \%(48)$ & Male & 2 & 22 & 3 & 11 & 8 \\
\hline & & Female & 5 & 19 & 2 & 10 & 7 \\
\hline & & Total \% & $3.63 \%(07)$ & $21.24 \%(41)$ & 5 & 21 & 15 \\
\hline \multirow[t]{3}{*}{$16-30$ yrs $(n=223)$} & $21.97 \%(49)$ & Male & 2 & 17 & - & 12 & 5 \\
\hline & & Female & 5 & 25 & - & 11 & 14 \\
\hline & & Total \% & $3.14 \%(07)$ & $18.83 \%(42)$ & - & 23 & 19 \\
\hline Grand Total $(n=479)$ & $29.65 \%(142)$ & Total & $7.52 \%(36)$ & $23.17 \%(111)$ & 16 & 56 & 39 \\
\hline
\end{tabular}

$\mathrm{n}=$ number of subjects

Table 11: Number and the Percentage (\%) of subjects showing no evidence of third molar formation (missing third molars). 
did not support the use of the third molar as an age indicator owing to difficulty in obtaining the radiograph and its anatomical variation. Although, third molar cannot be reliably implemented in estimation of exact chronological age, it may provide reasonable accuracy for the likelihood that a person is at least 18 years old $[21,24,25]$

Many advocates underscore the importance of third molar indicating the appropriateness of use of third molars as a developmental marker $[2,5,20,26]$. In spite of the variations, third molars are still at the centre of medicolegal interest; and its significance in age determination is justified as no other reliable age indicator is available to determine the age in adults [20]. Besides, it will be a great help to determine whether the adolescents have reached their eighteenth year of age or not as legal consequences will differ for juvenile detainees $[8,20,26]$.

\section{Conclusions}

In forensic odontology, if the age of the person can be accurately estimated it will significantly narrow the field of possible identities needed to establish a positive identification. The use of third molar teeth in age estimation has forever been questioned in the literature. Although the reliability of third molars in age estimation has been evaluated by several research groups, consensus on the usefulness of these teeth has not been reached. Third molar has always been categorised as a nonideal developmental marker owing to its variability, still it can be used as an aid in age estimation due to inaccuracy of skeletal predictors of age in adults.

The present study has discussed the utility of $3^{\text {rd }}$ molar in age estimation. Amongst the researches carried out so far very few studies including present study have addressed the transition zone between juveniles and adults by estimation of probabilities of individual to be 18 or older than 18 years of age. Third molars, if present and completely developed, at least they offer the possibility of an individual to be between 18 and 22 years of age. This research paper has evaluated third molar development with all associated variables to provide comprehensive information which might be valuable for future reference. Besides, third molar development shows definite ethnic variations; hence the outcomes needed to be interpreted in terms of population studied and thus universal norms may not be established at present $[27,28]$. This warrants the necessity of a more comprehensive research using larger sample size and the comparisons of the population-specific study outcomes in further extensions.

\section{References}

1. Nolla CM (1960) The development of permanent teeth. Journal Dentistry for Children 27: 254-266.

2. Arany S, lino M, Yoshioka N (2004) Radiographic survey of third molar development in relation to chronological age among Japanese juveniles. J Forensic Sci 49: 534-538

3. Willems G (2001) A review of the most commonly used dental age estimation techniques. J Forensic Odontostomatol 19: 9-17.

4. Ritz-Timme S, Cattaneo C, Collins MJ, Waite ER, Schütz HW, et al. (2000) Age estimation: the state of the art in relation to the specific demands of forensic practise. Int J Legal Med 113: 129-136.

5. Gunst K, Mesotten K, Carbonez A, Willems G (2003) Third molar root development in relation to chronological age: a large sample sized retrospective study. Forensic Sci Int 136: 52-57.

6. Thorson J, Hägg $\cup(1991)$ The accuracy and precision of the third mandibular molar as an indicator of chronological age. Swed Dent J 15: 15-22.

7. Ciapparelli L. (1992) The chronology of dental development and age assessment. In: Clark DH, (ed). Practical forensic odontology. Oxford: Wright Butterworth-Heinemann Ltd 22-42.
8. Masthan KMK. (2009) Age and sex. Textbook of forensic odontology. New Delhi: Jaypee Brothers Medical Publishers (P) Ltd .59-65.

9. Babar MG, Iqbal S, Jan A. (2008) Essential guidelines for forensic dentistry Pakistan Oral Dental Journal 27: 79-84.

10. Ardakani F, Bashardoust N, Sheikhha M (2007) The accuracy of denta panoramic radiography as an indicator of chronological age in Iranian individuals. J Forensic Odontostomatol 25: 30-35.

11. Bolanos MV, Manrique MC, Bolanos MJ, Briones MT (2000) Approaches to chronological age assessment based on dental calcification. Forensic Sci Int 110: 97-106.

12. Kullman L, Johanson $G$, Akesson $L$ (1992) Root development of the lower third molar and its relation to chronological age. Swed Dent J 16: 161-167.

13. Bolaños MV, Moussa H, Manrique MC, Bolaños MJ (2003) Radiographic evaluation of third molar development in Spanish children and young people. Forensic Sci Int 133: 212-219.

14. Ash MM, Nelson SJ. (2003) Chronology of permanent teeth. Wheelers Dental Anatomy, Physiology and Occlusion, 8th ed., Missouri: Suanders 15-18, 29-64.

15. Mesotten K, Gunst K, Carbonez A, Willems G (2002) Dental age estimation and third molars: a preliminary study. Forensic Sci Int 129: 110-115.

16. Chandramohan M, Shankar S, Hidhayathulla S, Vinay S, Ashwini OR. et al. (2010) Estimation of age using third molars among Indian juveniles: a retrospective analysis using panoramic radiographs. Journal of Oral Health Research 113-117.

17. Kullman L (1995) Accuracy of two dental and one skeletal age estimation method in Swedish adolescents. Forensic Sci Int 75: 225-236.

18. Gorgani N, Sullivan RE, DuBois L (1990) A radiographic investigation of thirdmolar development. ASDC J Dent Child 57: 106-110.

19. Uzamiş M, Kansu O, Taner TU, Alpar R (2000) Radiographic evaluation of third-molar development in a group of Turkish children. ASDC J Dent Child 67 136-141, 83

20. Solari AC, Abramovitch K (2002) The accuracy and precision of third molar development as an indicator of chronological age in Hispanics. J Forensic Sci 47: $531-535$.

21. Mincer HH, Harris EF, Berryman HE (1993) The A.B.F.O. study of third molar development and its use as an estimator of chronological age. J Forensic Sci 38: 379-390.

22. Bassed RB, Briggs C, Drummer OH (2011) Age Estimation and the Developing Third Molar Tooth: An Analysis of an Australian Population Using Computed Tomography. Journal of Forensic Sciences 56: 1185-1191.

23. Phrabhakaran N (1995) Age estimation using third molar development. Malays J Pathol 17: 31-34.

24. Garn SM, Lewis AB, Vicinus JH (1963) Third Molar Polymorphism and its Significance to dental Genetics. J Dent Res 42: S1344-1363.

25. Llarena del Rosario ME, Nuno Gonzalez MM (1990) Etapas de formacion y calcificacion del tercer molar. Rev. Adm 47: 112-117.

26. Olze A, Bilang D, Schmidt S, Wernecke KD, Geserick G, et al. (2005) Validation of common classification systems for assessing the mineralization of third molars. Int J Legal Med 119: 22-26.

27. Kasper KA, Austin D, Kvanli AH, Rios TR, Senn DR (2009) Reliability of third molar development for age estimation in a Texas Hispanic population: a comparison study. J Forensic Sci 54: 651-657.

28. Thevissen PW, Alqerban A, Asaumi J, Kahveci F, Kaur J, et al. (2010) Human dental age estimation using third molar developmental stages: Accuracy of age predictions not using country specific information. Forensic Sci Int 201: 106111

This article was originally published in a special issue, Forensic Odontology handled by Editor(s). Dr. Helena Ranta, University of Helsinki, Finland 